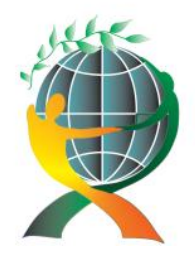

\author{
(online) $=$ ISSN $2285-3642$ \\ ISSN-L = $2285-3642$ \\ Journal of Economic Development, Environment and People \\ Volume 1, Issue 2, 2012 \\ URL: http://jedep.spiruharet.ro \\ e-mail: office jedep@spiruharet.ro
}

\title{
Sustainable urban structures to challenge climate change
}

\author{
Prof. dr. Emil CREANGA: ecreanga@yahoo.com \\ PhD Student Maria DUDA: maria.e.duda@gmail.com \\ University Spiru Haret Bucharest
}

\begin{abstract}
Public spaces within the city in all their form of different types - streets, boulevards, squares, plazas, market places, green areas - are the backbone of cities. Over the centuries buildings defined the shape and quality of public spaces, valorising them in various ways.

The post-modern development of urban form generated a great number of "urban spaces", where there is no longer correspondence between architectural forms and social and political messages: shopping malls and theme parks, inner public spaces, strip developments etc. Urban sprawl accompanied by loss of agricultural/rural land and its impact on the environment are serious concerns for most cities over Europe. To strike the right balance between inner city regeneration, under-use of urban land in the old abandoned sites and the ecological benefits that accompany the new private business initiatives in suburban areas, is one of the major challenges confronting cities in Europe.

The paper will analyze the complex relations between architecture and public space, in an attempt to understand how traditional urban structures, public and green spaces, squares and streets, could provide orientation for quality-oriented regeneration. Case in point is Bucharest - capital city of Romania - where aggressive intervention in the urban structure during the 1980s disrupted the fabric of the city. The investigation is oriented towards fundamental questions such as: how to secure and preserve sites that serve as initial points in upgrading processes, how to balance private investment criteria and the quality interests of the urban communities.

The major aim is to provide a support for decision making in restoring the fundamental role of public urban space in shaping urban form and supporting community life.
\end{abstract}

Keywords: public space, urban structure, regeneration, urban policy

\section{JEL Codes: Q54}




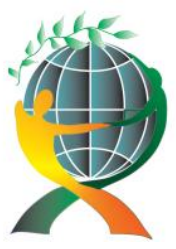

\author{
(online) $=$ ISSN $2285-3642$ \\ ISSN-L = $2285-3642$ \\ Journal of Economic Development, Environment and People \\ Volume 1, Issue 2, 2012 \\ URL: http://jedep.spiruharet.ro \\ e-mail: office jedep@spiruharet.ro
}

\section{Introduction}

As early as the 1960s Jane Jacobs commented on the complexity of cities "Cities happen to be problems in organized complexity...Cities ...do not exhibit one problem in organized complexity which if understood explains all.....The variables are many...they are interrelated in an organic whole". [1, p.446].

Urban structures of the $21^{\text {st }}$ century were shaped by an historical evolution process, influenced by geographical structures, political and cultural environments. For some decades now urban planners are concerned in promoting sustainable urban development, addressing a wide range of issues. Several approaches emerged, among which environmental issues took a leading place (green design, ecodesign), along with their implications on health, quality of life and on the society at large.

Among the latest challenges is climate change that in fact goes beyond environment protection, involving most economic, social, cultural aspects of urban life.

Yet, urban structures are resilient. Mitigating the effects of climate change requires a long-term strategic approach. To achieve sustainability under foreseeable new conditions design professionals should develop innovative and creative solutions that would address all the dimensions of sustainability in the urban environment.

This paper will investigate one of such approaches carried out by young architects-to-be. It addresses a priority issue of urban re-modeling of Bucharest: to enhance the importance of the river Dambovitza cutting through the city, widening water surfaces and increasing green areas, for the ultimate benefit of the quality of life of the inhabitants.

\section{The Context}

Bucharest is criss-crossed by two main rivers: Dambovitza which cuts northwest to south east, through its centre, and Colentina, which develops over a series of lakes in the northern part of the city.

Seasonal flooding of the city and sanitation needs prompted in the 1980s the administration to proceed to taming its course by having its bed covered in prefabricated concrete slabs. The river bed was enlarged twice the original size, thus getting shallower; the sewage mains of the city were placed under it.

Several bridges over the river were demolished, breaking connections between the banks and briskly interrupting several important historical roads. Pedestrian walkways along the river were reduced in their dimensions. Unfortunately the former rich, almost wild vegetation was replaced by scarce trees. No attempts to form a bankside promenade along the river or platforms for any kind of sailing or bathing facilities were planned or encouraged. The river lost its appeal, and its architectonic vocabulary discourages its being lived or integrated within the city. Nowadays isolated by the most trafficked street in Bucharest running both ways along it, it provides no natural solace for the city dweller. 


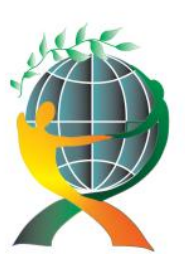

$$
\begin{gathered}
\text { (online) }=\text { ISSN } 2285-3642 \\
\text { ISSN-L }=2285-3642
\end{gathered}
$$

\section{Journal of Economic Development, Environment and People}

Volume 1, Issue 2, 2012

URL: http://jedep.spiruharet.ro

e-mail: office jedep@spiruharet.ro

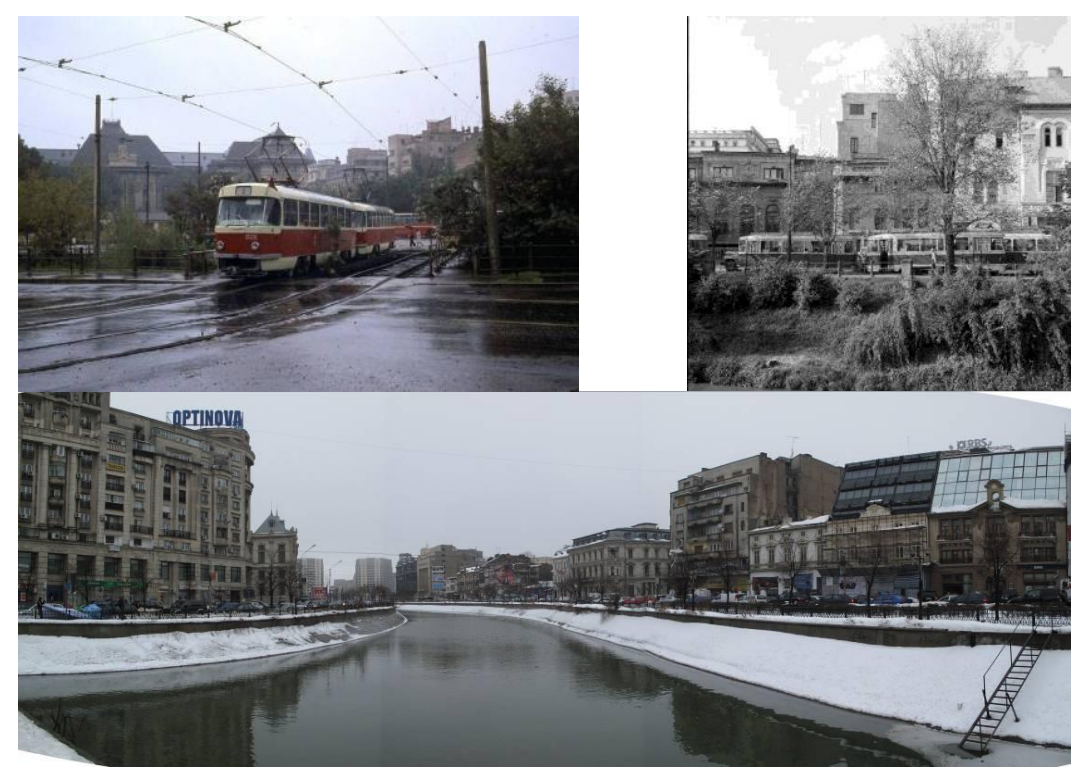

Fig.:.Above, the river in the late 1970s (rezistentaurbana.blogspot.com), and beneath, the river nowadays (personal archive)

And yet, despite its lack of planned social comfort and urban furnishing, Dambovitza's banks have been metabolized: on sunny days courageous fishermen lounge its concrete slopes, some even attempt swimming (although nowadays going for a splash in the monumental fountains is a more common and, to a certain extent, safer practice).

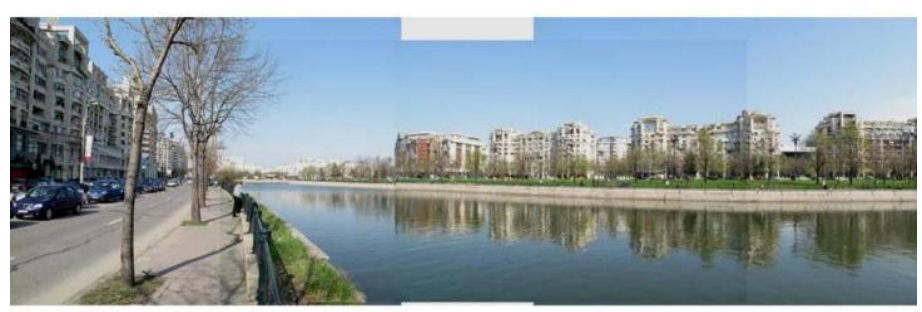

Fig.2: Dambovitza, eastern side (personal archive) 


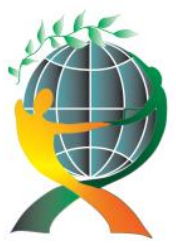

\author{
(online) $=$ ISSN $2285-3642$ \\ ISSN-L = $2285-3642$ \\ Journal of Economic Development, Environment and People \\ Volume 1, Issue 2, 2012
}

URL: http://jedep.spiruharet.ro

e-mail: office jedep@spiruharet.ro

In what concerns the new interventions though, the attitude of obstructing the relationship towards waterscapes still continues. Constructions of private capital limit themselves to the investor's area without taking into account the increased comfort a public space along the river would provide: the properties are usually fenced around. Moreover, the municipality does not get involved either: the river banks and lake sides remain unattended to, and no public infrastructure or furnishings are being considered. The following images portray the current situation in the northern part of Bucharest, along the Colentina River:

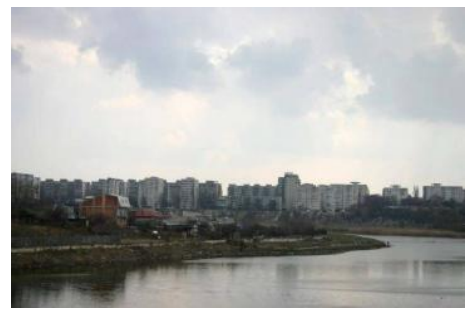

Fig.3: Pantelimon quarter (photo Vlad Nanca, bükreshblog.blogspot.com)

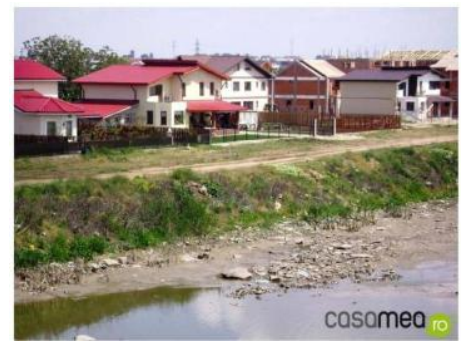

Fig.4:The Casamea residential villas (www.casamea.ro): no territorial intervention whatsoever upon integrating the river banks as public, common space for the neighborhood.

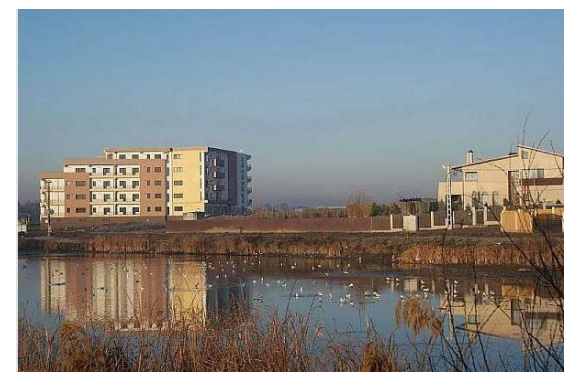

Fig.5: The (unintended) ironically entitled "Waterlily Lake" new housing ensemble in Chitila; fenced in (ansamblurirezidentiale.ro) 


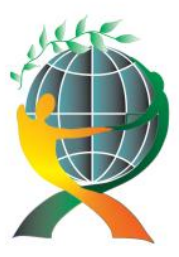

\author{
(online) $=$ ISSN $2285-3642$ \\ ISSN-L = $2285-3642$ \\ Journal of Economic Development, Environment and People \\ Volume 1, Issue 2, 2012 \\ URL: http://jedep.spiruharet.ro \\ e-mail: office jedep@spiruharet.ro
}

To second the urban intervention upon Dambovitza, a massive accumulation lake, Lacul Morii, was created upon it, in the North West side of Bucharest, holding a 246 ha surface. The role of the lake was to withhold any exceeding Dambovitza water that might have turned into flood. Walled by a $7 \mathrm{~km}$ long and some $5 \mathrm{~m}$ high continuous artificial hill topped with a concrete passageway, with only a few piercing staircases reaching its top, it is unperceived from the street level. Once at the top though, the image is impressive- it seems the whole city has been transported at the seaside, since the dimensions of the lake are as huge as the surprise of finding it there.

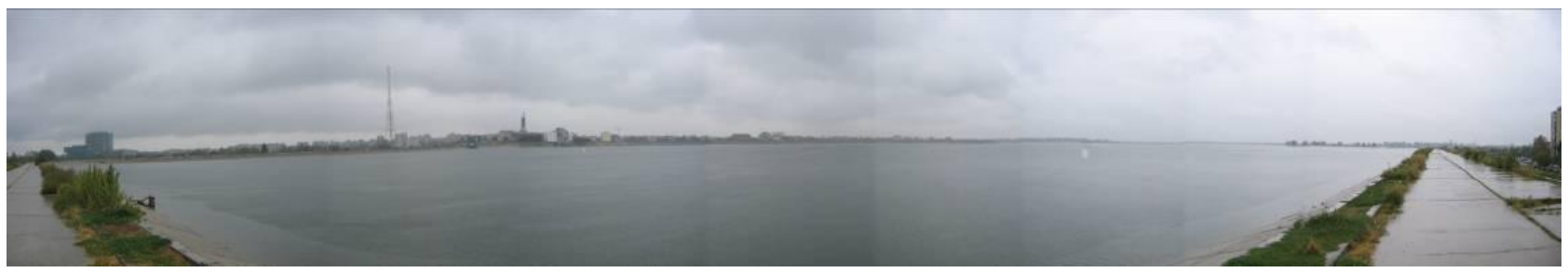

Fig.6: Morii Lake, 2009 (personal archive)

Although in this case the original goal of constructing the lake included using it as sportive infrastructure, the intention was never carried out. Excepting brave fishermen clinging to the slopey concrete banks, neighboring inhabitants washing their carpets and stray dogs, the lake attracts no one, taking on to being residual, hidden.
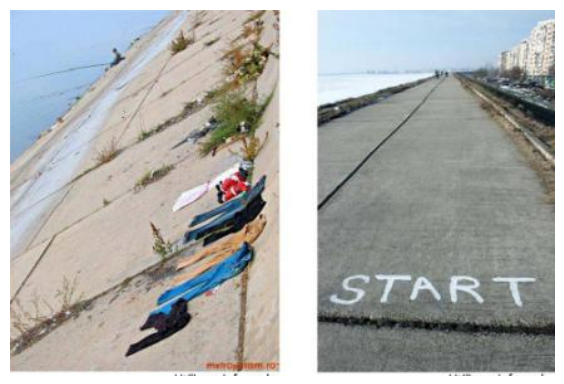

Fig.7: Lake banks poached as public space: fishing, washing and drying out, jogging tracks marked by dilatation joints (metropotam.ro, listenoire.ro)

Since 2007, marketing scouts have been attempting to place the island of the Morii Lake among the hip venues, organizing the CokeLive concert series. 


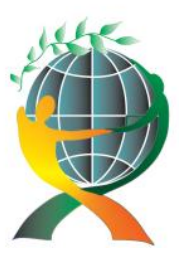

\author{
(online) $=$ ISSN $2285-3642$ \\ ISSN-L = $2285-3642$ \\ Journal of Economic Development, Environment and People \\ Volume 1, Issue 2, 2012
}

URL: http://jedep.spiruharet.ro

e-mail: office jedep@spiruharet.ro

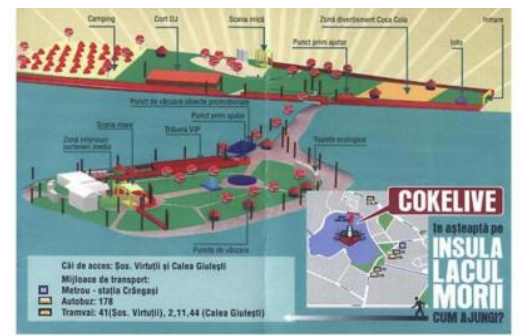

Fig.8: Cokelive 2007

\title{
3. A new dimension and role for the river
}

Last summer we put up a workshop for Urban Scenarios in order to Dis-still Bucharest; we approached the search for solutions starting from what Bucharest offers us, turning its problems into advantages and departure points towards a sustainable, feasible and characteristic development for both the city and its users. We had 13 students participating, organized in five teams, each having chosen a keyword as theme. The aim of the workshop was the production of one manifesto for each theme; on one hand a manifesto gives a decisive character to the proposal, on the other hand it draws the public's, the city users' attention.

We are going to present you the work of two students who chose Water as their keyword; the curious inconspicuousness of the Dambovitza River inside the city being the challenge in the approach of their project.

After carrying out an analysis of functions along its banks and their scarce connection to the water front, a quite radical and strategic idea sprung out: dividing the banks according to traffic use. One bank would become pedestrian and open towards the river, allowing users to benefit from its presence, while the other bank would take in all private car traffic.
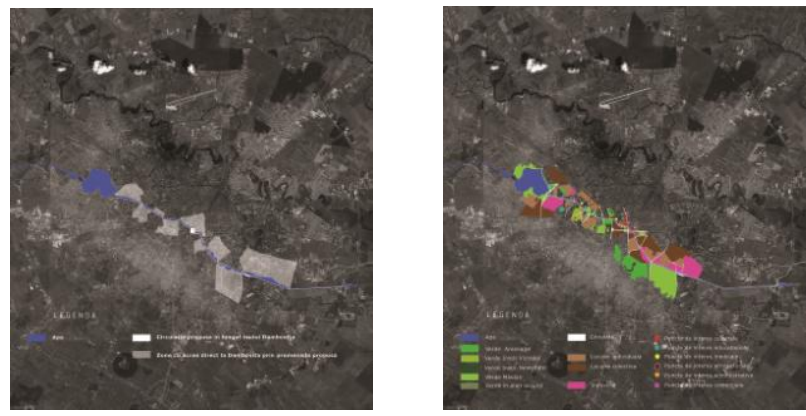

Fig. 9. Pedestrian and open towards the river and private car traffic.

The division follows the functions along the river: areas of public interest, cultural zones and residential neighbourhoods would be served only by public transportation and their banks would be topographically remodeled in an organic, free manner, enabling the public to come into direct contact with the river. The other 


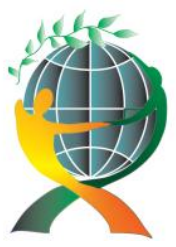

\author{
(online) $=$ ISSN $2285-3642$ \\ ISSN-L = $2285-3642$ \\ Journal of Economic Development, Environment and People \\ Volume 1, Issue 2, 2012 \\ URL: http://jedep.spiruharet.ro \\ e-mail: office jedep@spiruharet.ro
}

functions would benefit private car traffic and a more remote approach to the river side. The banks thus alternate in their use, but both integrate the river in the urban space and users' daily life.

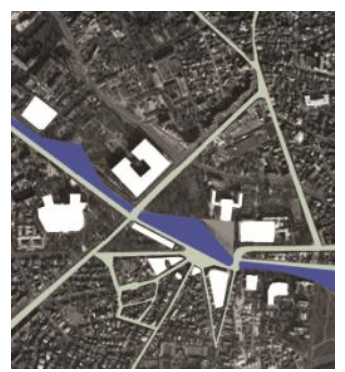

Fig. 10: Banks thus alternate in their use

Their manifesto focuses on the Opera Plaza.

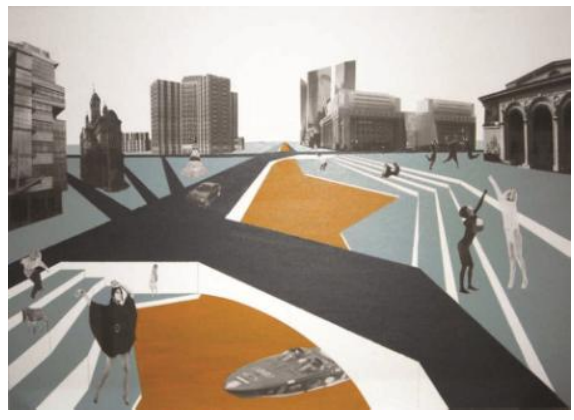

Fig. 11: Opera Plaza

\title{
4. Conclusions
}

The case study presented above is but an example of how can traditional urban structures provide orientation for a new type of development that would contribute to mitigating climate change in our cities.

A number of other priority issues may be dealt with, such as inner-city green areas, re-use of brown fields within the city. They are of great importance both for the quality of urban life and could contribute to mitigating climate change.

We believe that scientific exchange, knowledge transfer, complex cooperative actions between countries of our region would foster a pool of knowledge in the interest of sustainable development in 


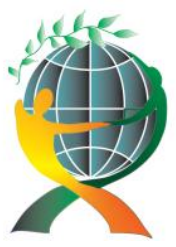

\author{
(online) $=$ ISSN $2285-3642$ \\ ISSN-L = $2285-3642$ \\ Journal of Economic Development, Environment and People \\ Volume 1, Issue 2, 2012 \\ URL: http://jedep.spiruharet.ro \\ e-mail: office jedep@spiruharet.ro
}

South East Europe. We should tap on the creative potential of young professionals and students in finding solutions that would solve future problems, namely by:

$\checkmark$ identifying priority areas of action

$\checkmark$ devising new methods of understanding the context of urban design

$\checkmark$ finding methods of testing and predicting the consequences of development proposals.

\title{
5. References
}

[1] Jacob, J. (1961) The death and life of great American cities. London, Penguin Books

[2] Cooper, R., Evans, Gr., Boyko, Chr., ed.: Designing Sustainable Cities. WILEY-BLACKWELL.2009 